\title{
Islamic Work Ethics and Audit Opinions: Audit Professionalism and Dysfunctional Behavior as Intervening Variables
}

\author{
Tulus Suryanto
}

\begin{abstract}
Islamic Work Ethics and Audit Opinions: Audit Professionalism and Dysfunctional Behavior as Intervening Variables. This study examines the relationship between Islamic work ethics and auditors' opinion, focusing on the aspects of audit professionalism and dysfunctional behavior as intervening variables. The research involved in Internal Auditors working of Islamic Banking industry in Sumatra Island. A questionnaire was used for data collection. The study represents the empirical test employing census sampling. The data collected were analysed using Amos. The results of the study confirmed the three hypotheses examined: there is a positive corelation between Islamic work ethics and auditors' opinions; auditors' professionalism is an intervening variable of the correlation between Islamic work ethics and auditors' opinions and dysfunctional behavior is a negative intervening variable of the correlation between Islamic Work Ethics and auditors'opinions."
\end{abstract}

Keywords: Islamic Work Ethics; Audit Professionalism; Dysfunctional Behavior; Auditors' Opinions

\begin{abstract}
Abstrak. Etika Kerja Islami dan Opini Audit: Profesionalisme Audit dan Prilaku Disfungsional sebagai Variabel Intervensi. Penelitian ini menguji hubungan etika kerja Islam dan pendapat auditor, berfokus pada aspek profesionalisme audit dan perilaku disfungsional sebagai variabel intervening. Penelitian melibatkan auditor yang bekerja di Industri Perbankan Islam di Pulau Sumatera. Kuesioner digunakan untuk pengumpulan data. Penelitian ini merupakan uji empiris menggunakan sensus sampling. Data yang dikumpulkan dianalisis menggunakan program Amos. Hasil penelitian menegaskan tiga hipotesis diperiksa: ada korelasi positif antara etika kerja Islam dan opini auditor; auditor profesionalisme adalah variabel moderator dari korelasi antara etika kerja Islam dan auditor pendapat; perilaku disfungsional adalah variabel negatif moderator dari korelasi antara Etika Islam Kerja dan opini auditor.
\end{abstract}

Kata kunci: Etika Kerja Islam; Profesionalisme Audit; Perilaku Disfungsional; Opini Auditor 


\section{Introduction}

In the process of making investment decisions, investors tend to invest in companies concerned with social and environmental issues (Pinnarwan in Zuhroh and Sukmawati, 2003). Based on reseach of Deegan (1997) Belkaoui (1999) and Anggraini (2006) showed that companies which reveal social information to investors will certainly gain public trust. The increase of public trust is expected to lead to the increase of the stock trading volume and stock returns in the companies. This could be considered as the driving force of investors' reactions in making investment decisions.

To attract investors, companies have to work hard in order to present reports which are free from misstatements and irregularities or fraud. According to SAS no. 99, there are four types of pressure that may lead to fraud in financial statements: financial stability, external pressure, personal financial need, and financial targets. Financial statement fraud often begins with misstatements or management-quarter earnings from financial statements considered not material; these eventually grow into massive fraud and produce misleading annual financial statements (Rezaee, 2002). Cheating on financial statements will result in misperceptions of auditors and other users of financial statements, because they do not show the actual condition of the companies. This will necessarily bring the impact of losses for businesses

One way the management of a company can prevent fraud is by focusing on the dividend policy. A company's dividend policy has important implications for many parties involved in the community, because it determines whether the profits which the company makes will be distributed to shareholders as dividends or be detained in the form of retained earnings in order to finance an investment in the future (Agus, 2001). The devidend policy is an indicator of the earning quality of the company; this has an impact on the corporate profites presented in the financial statements. The dividend policy applied by the management of the company to manage their finances will help to reduce the occurrence of fraud in earnings manipulation. Furthermore, information technology can be used to assist the company in carrying out day-to-day operations. The implementation of information technology will increase the performance of the company. This minimizes the opportunity of fraud to occur in the company. In addition to information technology, another factor that is important in the prevention of fraud is accounting report. Accounting report is an essential component of organizational accountability. The great demand of the implementation of public accountability has an implication for the way the management provides information to the public; one of which is the accounting informarion in the form of financial statements. One of the challenges of accounting reporting is whether 
it is able to provide information which can be used to monitor the management accountability, political accountability, and accountabiliy policies. One form of fraud prevention is the presentation of true accounting reporting which considers the implementation of policies, systems and procedures to assure that necessary actions have been carried out by commissioners, as well as the management and other personnels.

This study examines the effect of the dividend policy, the application of information technology, and the accounting and reporting on fraud prevention. Additionally, it investigates whether the reaction of investors, as a moderating variable, influences such variables as the dividend policy, the application of information technology, and the accounting reporting.

\section{Literature Review}

This study aims to describe the correlation between attitudes and behavior of individuals, especially the auditors in carrying out the audit process. The Theory of Reasoned Action (TRA), proposed by Fishbein and Ajzen (1975), is a theory related to the attitudes and behavior of individuals in implementing grounded activities/ actions (reasoned actions). Many previous research which using TRA Model, Hansen et al (2004) examined behavior of consumers to use online shopping method by using concept of Theory of reasoned action. The research proves that the theory of reasoned action is appropriate theory to predict consumer behavior in online shopping. Other research conducted by Njite et al (2005) which examines application of Theory reasoned action in influencing consumer to use online shopping through internet services. The result supports research by Hansen et.al (2004) which proves that the Theory of reasoned action is a appropriate theory to predict human behavior.

In this case, we use Theory of Reasoned Action to explain of auditor behavior. An auditor is required to be professional and to obey audit ethics in implementing the audit process. TRA is able to explain the attitudes of auditors in the audit process, whether they do their job professionally or there is an element of dysfunctional behavior.

One way of realizing public accounting professional conduct is the implementation of professional ethics established by Ikatan Akuntan Indonesia (IAI), namely the Code of Ethics of Indonesian Accountants. Ethics can be defined as a set of moral principles or values (Elder et al., 2011). Regarding to ethics, a profession should have a high moral commitment that is manifested in a special regulation. This rule guides the way the profession is run or carried out, commonly referred to as ethics code. Code of ethics is created with the aim to 
Al-Iqtishad: Jurnal Ilmu Ekonomi Syariah (Journal of Islamic Economics) Vol. 8 (1), January 2016

set standards of behavior for accountants, especially CPAs. Code of professional conduct is based on the following reasons: first, the need for public confidence in the quality of services rendered; Second, people cannot be expected to assess the quality of services rendered by the profession; Third, increased competition among members of the profession.

The Indonesian Accountants ethical code is a code of conduct that consists of: First, the general provisions in the code of ethics of public accountants which have strength in terms of the emphasis on positive activities to produce high quality work. Minimum standards of behaviour should exist in the profession; Second, specific rules containing detailed explanations, which guide the implementation of the minimum standards of conduct and performance. This will assist in understanding the ethical code, which should be interpreted as a maximum standard rather than as a minimum one. In the perspective of Islam, work ethics can be interpreted as ethics which include the values of the Qur'an. A number of key parameters have been established for the Islamic ethical system. The parameters are as follows (Muhammad, 2004): first, various actions or decisions referring to the ethics depend on individuals' intentions. Allah the almighty knows the intentions fully and completely; Second, good intentions followed by good actions will be counted as worship. Kosher intentions cannot change the actions to either be halal or haram; Third, Islam gives freedom to individuals to believe and act upon any desire, but not in terms of responsibility and justice; Fourth, believing in Allah gives individuals complete freedom from anything or anyone except Allah; Fifth, decisions that benefit the majority or the minority are not directly ethical in itself; Sixth, Islam uses an open approach to ethics, not a closed system. Selfishness has no place in Islam; Seven, ethical decisions should be based on an understanding of the Qur'an and the universe; Eight, unlike other ethical systems which are used by other religions, Islam encourages mankind to carry out Tazkiyah through active participation in life. By behaving ethically in life, muslims must be able to prove his obedience to God.

An audit opinion is given by an auditor on the presentation of financial statements of the company where the auditor conducts the audit. The audit opinion is reflected by the opinion paragraph included in the audit report section. Therefore, the audit opinion is an integral part of the audit report. The audit report informs the users of information about what the auditor and the conclusions obtained. "Statements of the auditor's opinion must be based on an audit carried out by auditing standards and findings." (SA Section 508, IAPI, 2011). There are five types of opinion statements that may be given by a public accountant auditing financial statements, as described in section 508, SPAP (2011): an unqualified 
opinion, an unqualified opinion with an explanatory language, a qualifying opinion, an unreasonable opinion, and the statements do not contain opinions. A basic aspect that must be considered by an auditor is ethics in the profession. The implementation of professional works cannot be separated from ethics because professional behavior is necessary for all professions requiring the trust of the public. The American Heritage Directory (in Gusti and Ali, 2008) defines ethics as a set of rules or standards determining the behavior of members of a profession. With a high ethical awareness, an auditor can carry out their duties professionally in accordance with the code of ethics and auditing standards, so that the results of audits will be more indicative of the actual situation in the provision of audit opinion. Someone who obeys the work ethics of Islam will have a commitment to the profession. The work ethics of Islam teach that a work is a virtue, making a person become a person responsible for the profession and do his/her job with honesty and sincerity. Panemon (in Aji \& Sabeni, 2003) states that the commitment to the profession can be produced from the process of acculturation and assimilation at the time when individuals enter the profession, also when the individuals choose to stay in the profession. Further, he proposes that the ethical behavior of auditors is associated with the auditors' high commitment to the profession. In the case of practicing a profession, individuals' accountability is not only related to leadership, but also to their relationship with God. This is because human beings are considered as God's servants who should realize the socioeconomic justice in the world and the hereafter (Burhanuddin, 1996 in Aji and Sabeni, 2003). Suraida's (2005) study indicates that ethical factors have a positive influence on the precision of the provision of auditors' opinions. The results of the study could be used as a reference suggesting that ethics also affect the accuracy of auditors' opinions. Based on these descriptions, the proposed hypotheses are as follows:

H1: There is a influence between Islamic Work Ethics to the precision of auditors' opinions.

Simply put, professionalism means that an auditor shall carry out his/ her tasks with seriousness and rigor. As a professional, the auditor should avoid negligence and dishonesty. Arens et al. (in Noveria, 2006) defines professionalism as an individual's responsibility to behave better than just complying with laws and regulations existing in the society. Professionalism is also an element of motivation that contributes to an individual's high job performance (Guntur et al., in Ifada $\&$ M. Jafar, 2005). Determining the level of opinions of financial statements is not easy. Many factors influence auditors' considerations in determining their opinions, including the professionalism of the auditors. The more professional an auditor 
is, the better their considerations and professional ethics are, particularly with the implementation of the Islamic work ethics in the executions of tasks; internal auditors will not commit fraud in determining the level of materiality. Herawaty and Susanto (2008) examined the professionalism and knowledge of public accountants in the detection of errors, professional ethics and materiality level considerations. The results indicate that professionalism has positive regression coefficient $(0.231)$; therefore, it is significant.

The Islamic work ethics guiding an auditor is expected to increase his/her level of professionalism in the audit process; thus, the auditor can produce reasonable opinions without cheating and manipulation. In this case, the developed hypothesis is as follows:

$\mathrm{H} 2$ : The effects of Islamic Work Ethics on audit opinions are mediated by the professionalism of auditors

Auditors' work in generating opinions will not be successful if it is not accompanied by the auditors' behaviours that support the audit process. According to Jaworski and Young (1992), the dysfunctional behavior can be defined as 'an act in which an attempt is made less than the maximum by manipulating elements of the control system with the desired destination'. The Islamic work ethics will help to produce a reasonable audit opinion if it is not influenced by the dysfunctional behaviour of auditors. The research of Soobaroyen (2006) suggests that the dysfuntional behavior has a negative direct effect on the performance of auditors, and thus, on the results of the process. The hypothesis is formulated as follows:

H3: The Islamic work ethics will help to produce a reasonable audit opinion if it is not influenced by the dysfunctional behavior of auditors.

\section{Methods}

The population in this study is the Islamic banking industry Sumatra, Indonesia. The participants were internal auditors whose religion is Islam and working in Islamic banks. It is assumed that Muslim auditors better understand their religion and practice it in their work environments. Additionally, the auditors must have a minimum term of one year, with a consideration that the auditors have the time and experience to adapt to their work settings, and self-assess the work settings so as to identify and determine appropriate responses to questions in the questionnaire related to the variables of the study.

In this research, we use of census sampling method for primary data collection by means questioner distribution, tabulation and presentation respondents 
characteristic. Tabulation of the satisfactory results of data quality test use reliability test and validity test.

Reability test by means of value of Cronbac's Alpha as well as validity test by means of bivariate Pearson correlation between constructs for accomplishing meaningful empirical research on the subject (Ballen, in Ghozali, 2005). The hypothesis test use Amos ver 20.

\section{Results and Discussion}

This study employed a questionnaire as a research instrument for collecting primary data from the participants. The primary data refer to the respondents' responses. The questionnaire was distributed to the respondents by visiting them directly or by sending the questionnaire by mail to the respondents, particularly those outside the area of Bandar Lampung Province.

Table 1. The Characteristics of Respondents

\begin{tabular}{llcc}
\hline No & \multicolumn{1}{c}{ Information } & Total & Percentage (\%) \\
\hline 1. Gander & 44 & 77,19 \\
& Male & 13 & 22,81 \\
& Female & 57 & 100 \\
$\quad$ The number of questionnaires that can be processed & & \\
2. Age & 10 & 17,54 \\
& $\leq 40$ years old & 47 & 82,46 \\
Aged $>40$ years & 57 & 100 \\
$\quad$ The number of questionnaires that can be processed & & \\
\hline
\end{tabular}

Source: primary data were processed, 2014

Questionnaires were distributed to Islamic banking offices in Bandar Lampung, ranging from 1 to 15 questionnaires. They were specifically tailored to meet the demands of the banks. The number of questionnaires sent by mail to several Islamic banking offices outside Bandar Lampung province was 10. A hundred and twenty two participants filled out the questionnaires; sixty six respondents returned them. In light of the above fact of low response rate has implication for the integrity of the sample. The characteristics of the respondents were obtained from data collected using the questionnaires (Table 1). 
Al-Iqtishad: Jurnal Ilmu Ekonomi Syariah (Journal of Islamic Economics)

Table 2. Reliability Test Results

\begin{tabular}{cccc}
\hline No & Variable & Cronbach Alpha value & Information \\
\hline 1 & Islamic Work Ethics & 0,773 & Reliable \\
2 & Professionalism in Audit & 0,683 & Reliable \\
3 & dysfunctional Behavior & 0,622 & Reliable \\
4 & Audit opinion & 0,889 & Reliable \\
\hline
\end{tabular}

Source: Primary data processed in 2014

The data quality test includes reliability and validity tests. The reliability test was conducted with the Cronbach alpha test using SPSS. A construct is said to be reliable if it provides the value of Cronbach alpha $>0.60$ (Nunnaly, in Ghozali, 2004). The results of the reliability test are presented in Table 2.

The validity test was performed by examining the bivariate correlation (Pearson correlation) between the respective indicator scores and the total score of constructs. An indicator of the question is considered valid if the correlation between each indicator show significant results. The results of the validity test are presented in Table 3.

Table 3. Validity Test Result

\begin{tabular}{clccc}
\hline No & \multicolumn{1}{c}{ Variable } & $\begin{array}{c}\text { Range of } \\
\text { correlation }\end{array}$ & Significant & Information \\
\hline 1 & Islamic Work Ethics & $0,16-0,74^{* *}$ & 0,01 & Valid \\
2 & Professionalism in Audit & $0,03-0,76^{* *}$ & 0,01 & Valid \\
3 & Dysfunctional Behavior & $0,12-0,57^{* *}$ & 0,01 & Valid \\
4 & Audit opinion & $0,58-0,82^{* *}$ & 0,01 & Valid \\
\hline
\end{tabular}

Source: Primary data processed in 2014.

Note: ${ }^{* *}$ means the significance of the correlation 
After being tested for normality and outliers using Amos, the data can be submitted for filing the hypotheses. The comparison of models, built by the cut of goodness of fit indices, is set (Table 4).

Table 4. Goodness Of Fit

\begin{tabular}{cccc}
\hline Goodness of fit index & Cut off Value & Result Model & Information \\
\hline Chi-Square & $\geq 0.05$ & 72.886 & Fit \\
Probability & $\leq 2.00$ & 1.181 & Fit \\
CMIN/DF & $\geq 0.90$ & 0.910 & Fit \\
GFI & $\geq 0.90$ & 0.935 & Fit \\
AGFI & $\geq 0.95$ & 0.985 & Fit \\
TLI & $\geq 0.90$ & 0.933 & Fit \\
CFI & $\leq 0.08$ & 0.074 & Fit \\
RMSEA & & & Fit \\
\hline
\end{tabular}

In light of contents of Table 4, the Goodness Of Fit Indicies show acceptable fit. The testing of the hypotheses can be examined from the magnitude and probability of Critical Ratio and the output regression weight (Table 5).

The first hypothesis (H1) is that there is a influence between the Islamic work ethics to the precision of auditors in giving opinions. The test results of the estimation parameters (standardized regression weight) between Islamic work ethics to the precision of auditors in giving opinions showed there are positive effect amount of 1231, with the value of the critical ratio (CR) of 3.359 and p-value of 0 . The $C R$ value is way above the critical value of \pm 1.96 significance level of 0 (ie. significant), that $\mathrm{p}$ is under significant value of 0:05. It means there is a influence between the Islamic work ethics to the precision of auditors in giving opinions. Therefore, the first hypothesis can be accepted. 
Al-Iqtishad: Jurnal Ilmu Ekonomi Syariah (Journal of Islamic Economics) Vol. 8 (1), January 2016

Table 5. Full Model Regression Weights

\begin{tabular}{|c|c|c|c|c|c|c|c|}
\hline & & & $\begin{array}{l}\text { Standardized } \\
\text { regression } \\
\text { weight }\end{array}$ & $\begin{array}{l}\text { Standardized } \\
\text { Estimate }\end{array}$ & $\begin{array}{l}\text { Critical } \\
\text { Ratio } \\
\text { (CR) }\end{array}$ & $\begin{array}{c}\mathrm{P}- \\
\text { value }\end{array}$ & Label \\
\hline PA & $<--$ & EI & 0,983 & 0,145 & 5,213 & 0 & par-4 \\
\hline $\mathrm{DB}$ & $<--$ & EI & 0,935 & 0,23 & 3,216 & 0,027 & par-2 \\
\hline DB & $<--$ & PA & 0,005 & 0,393 & 2,074 & 0,881 & par-7 \\
\hline $\mathrm{OA}$ & $<--$ & EI & 1,231 & 1,339 & 3,359 & 0,646 & par-3 \\
\hline $\mathrm{OA}$ & $<--$ & PA & 0,792 & 0,453 & 2,113 & 0,267 & par-5 \\
\hline $\mathrm{OA}$ & $<--$ & DB & 1,466 & 1,318 & 0,721 & 0,502 & par-6 \\
\hline $\mathrm{x} 5$ & $<--$ & EI & 1 & & & & \\
\hline $\mathrm{x} 2$ & $<--$ & EI & 1 & & & & \\
\hline $\mathrm{x} 7$ & $<--$ & PA & 1 & & & & \\
\hline $\mathrm{x} 8$ & $<--$ & PA & 1 & & & & \\
\hline x9 & $<--$ & PA & 1 & & & & \\
\hline $\mathrm{x} 15$ & $<--$ & OA & 1 & & & & \\
\hline x19 & $<--$ & OA & 1,007 & 0,127 & 7,899 & 0 & par-1 \\
\hline $\mathrm{x} 22$ & $<--$ & OA & 1 & & & & \\
\hline $\mathrm{x} 14$ & $<--$ & PA & 1 & & & & \\
\hline x12 & $<--$ & PA & 1 & & & & \\
\hline $\mathrm{x} 10$ & $<--$ & PA & 1 & & & & \\
\hline
\end{tabular}

Source: Data processed, 2014

$\mathrm{EI}=$ Islamic Work Ethics

$\mathrm{PO}=$ Professionalism Audit

$\mathrm{DB}=$ Dysfunctional Behavior

$\mathrm{OA}=$ Audit Opinion 
The results of this study are consistent with Kusuma's (2012) research which suggests that the professional ethics have a significant positive effect on the level of materiality considerations of public accountants in providing an opinion. Furthermore, the results also highlight the study conducted by Sukmawati (2014) which indicates that professional ethics is related to audit opinions. Every public accountant is expected to hold the firm professional ethics which has been established by the Indonesian Institute of Certified Public Accountants, so that unfair competitions can be avoided. Similarly, the Islamic work ethics will make internal auditors understand Islamic banking norms; thus, they will be more committed to the profession. Ethics is important for the accounting profession as it is a provider of information for business decision-making processes. By upholding the professional ethics, it is expected that cheating does not occur among auditors. Thus, the auditors' opinions are in accordance with financial statements presented.

Hypothesis 2 is that the effects of Islamic Work Ethics on audit opinions are mediated by the professionalism of auditors. For hypothesis 2, we use standardized direct effect to analyse the second hypothesis

Table. 6. Standardized Direct Effect

\begin{tabular}{ccccc}
\hline & EI & PA & DB & OA \\
\hline PA & 0,983 & 0 & 0 & 0 \\
DB & 0,935 & 0,005 & 0 & 0 \\
OA & 1,231 & 0,793 & 1,466 & 0 \\
\hline
\end{tabular}

The direct effect is the loading factor or lambda value of each indicator that form latent variables; they were analyzed (Agusty, 2001). To determine the effect, the constructs of the work ethics of Islam (EI) was closely examined through intermediate variables of professionalism audits (PA) to the audit opinion (OA).

Table. 7. The indirect influence of Islamic Work Ethics through intermediate variables of Professionalism Audit to the Opinion Audit

\begin{tabular}{cccc}
\hline Lane & $\begin{array}{c}\text { The direct effect } \\
\text { EI-PA }\end{array}$ & $\begin{array}{c}\text { The direct effect } \\
\text { PA-OA }\end{array}$ & The indirect effect EI-PA-OA \\
\hline & A & B & $($ a X b) \\
EI-PA-OA & 0.983 & 0.793 & 0.779 \\
\hline
\end{tabular}


The indirect influence of Islamic work ethics to professional audit and audit opinion is 0.779 . That implies that audit professionalism is proven to mediate Islamic work ethics and audit opinion. Therefore, hypothesis two, that Islamic work ethics and audit opinion are mediated by professionalism, can be accepted. An auditor is expected to uphold the Professional Ethics which has been established by the Indonesian Institute of Certified Public Accountants, so that unfair competitions can be avoided. Ethics is important for the profession because it provides information for business decision-making process. Internal auditors of Islamic banking should uphold Islamic work ethics, so that their level of professionalism will be higher. This will prevent fraud, as the auditors' opinions are in accordance with financial statements presented by the company. Internal auditors of Islamic banking that really understand and apply the work ethics of Islam will be easier to commit to the organization. This could improve the professional level so as to produce a good performance. The results of this study are consistent with the results of research conducted by Herath and Susanto (2009), which provides evidence that Professional Ethics has a positive effect on provision of audit opinion. This study also supports research conducted by Wahyudi et al. (2014) which proves that professional audit is one decisive factor in the provision of audit opinion.

Hypothesis three is the influence of Islamic work ethics toward audit opinion is negatively mediated by dysfunctional behavior. For hypothesis three a model that connects the indirect effect constructs the work ethic of Islam (EI) through intermediate variables dysfunctional behavior (DB) of the Opinion Audit (OA) has been developed.

Table. 8. Work Ethics indirect influence of Islam through intermediate variables Dysfunctional Behavior of the Opinion Audit

\begin{tabular}{cccc}
\hline Lane & $\begin{array}{c}\text { The direct } \\
\text { effect EI-DB }\end{array}$ & $\begin{array}{c}\text { The direct effect } \\
\text { DB-OA }\end{array}$ & $\begin{array}{c}\text { The indirect effect } \\
\text { EI-DB-OA }\end{array}$ \\
\hline A & B & $(\mathrm{a} \mathrm{X} \mathrm{b)}$ \\
EI-DB-OA & 0.935 & 1.466 & 1.370 \\
\hline
\end{tabular}

The indirect influence of Islamic work ethics toward audit opinion through Dysfunctional behavior is amounted to 1.370 . That implies that dysfunctional behavior is proven to negatively mediate Islamic work ethics and audit opinion. 
Therefore, hypothesis three can be accepted. The audit process will not be succesful in generating opinion if it is not accompanied by auditors' behaviour which supports the process. According to Jaworski and Young (1992), dysfunctional behavior can be defined as "an act in which an attempt is made less than the maximum by manipulating elements of the control system with the desired destination”. Islamic work ethics, accompanied with dysfuntional behavior, will certainly have a negative impact on audit work processes. Because of this, auditors' opinions could become incompatible with real situations happening in the companies they audit. To sum up, the relationship of the Islamic work ethics and audit opinions will not be effective if it is influenced by dysfunctional attitudes. This is consistent with research done by Soobaroyen (2004) and Wiyantoro (2006) which suggest that dysfuntional behavior has a direct negative effect on the performance and the outcome of the audit process.

There are several recommendations according these results, such as: First, auditors need to increase knowledge that can support their consideration in determining opinions on financial statements; Second, collegial relationship needs to be improved to help auditors establish good communication, so that there are no different perceptions among the auditors; Third, in performing their duties, auditors must comply with the Professional Ethics which has been set by professional organizations, so they do not act based on their personal preferences; Fourth, the development of research instruments should be adjusted to the conditions and environments of the objects to be examined;

\section{Conclusion}

There is a positive coorelation between the work ethics of Islam with auditors' precision in giving opinions. The results of this study are consistent with research conducted by Kusuma (2012) and Sukmawati (2014), which suggests that professional ethics is closely related to audit opinions. Ethics is important in the accounting profession because it provides information for business decision-making processes. By upholding the work ethics of Islam, it is expected that cheating does not occur among auditors of Islamic banking, so that the auditors' opinions are inaccordance with the financial statements presented.

Professional audit is proven to mediate Islamic work ethics and audit opinion. The results of this study are consistent with the results of research conducted by Herath and Susanto (2009); it also supports the research of Wahyudi et al. (2014) which suggests that professional audit is one decisive factor in the provision of audit opinion. By upholding the work ethics of Islam, auditors' level of professionalism will be higher, as more professional audits will prevent fraud among internal auditors 
of Islamic banking. This is because the audit opinions are in accordance with the financial statements presented by the company.

Dysfunctional behavior is proven to negatively mediate Islamic work ethics and audit opinion. The results of this study suggest that due to dysfunctional behaviour, which violates ethical and professional attitudes, the audit opinion becomes incompatible with real situations happening in companies. To sum up, the effect of the work ethics of Islam on the audit opinion will not be effective if auditors' behavior is influenced by dysfuntional factors. This is consistent with research done by Soobaroyen (2004) and Wiyantoro (2006), which indicate that dysfuntional behavior has a direct negative effect on the performance or the outcome of the audit process.

\section{References}

Anggraini, R. (2006). Pengungkapan Informasi Sosial dan Faktor-Faktor yang Mempengaruhi Pengungkapan Informasi Sosial dalam Laporan Keuangan Tahunan (Studi Empiris pada Perusahaan-Perusahaan yang terdaftar Bursa Efek Jakarta). Simposium Nasional Akuntansi 9. Agustus 2006

Arifuddin \& Anik, S. (2002). Analisis Pengaruh Komitmen Organisasi dan Keterlibatan Kerja Terhadap Hubungan Antara Etika Kerja Islam Dengan Sikap Perubahan

Organisasi. Simposium Nasional Akuntansi V. September 2002

Arrens, L. (2002). Auditing. Jakarta: Salemba Empat.

Belkaoui, A. \& Karpik, P.G. (1989). Determinants of the Corporate Decision to Disclose Sosial Information. Accounting, Auditing and Accountability Journal. Vol. 2, No. 1, pp. 36- 51

Deegan, C. \& Rankin, M. (1997). The Materiality of Environmental Information to Users of Annual Reports. Accounting, Auditing and Accountability Journal. Vol. 10, No. 4, pp. 562-584.

Elder, R.J, et al. (2011). Jasa Audit dan Assurance: Pendekatan Terpadu (Adaptasi Indonesia). Jakarta: Salemba Empat.

Ghozali, I. (2004). Model persamaan structural, konsep dan aplikasi dengan aligment program AMOS Ver.5.0”. Semarang: Badan Penerbit Universitas Diponegoro.

Ghozali, I. (2006). Aplikasi Analisis Multivariate dengan program SPSS. Semarang: Badan Penerbit Universitas Diponegoro.

Gusti, M \& Ali, S. (2008). Hubungan Skeptisisme Profesional Auditor dan Situasi Etika, Pengalaman serta Keahlian Audit dengan Ketepatan Pemberian Opini Auditor oleh Akuntan Publik. Jurnal Simposium Nasional Akuntansi XI. 
Herawati \& Susanto. (2009). Pengaruh Profesionalisme, Pengetahuan Mendeteksi Kekeliruan dan Etika Profesi terhadap Pertimbangan Tingkat Materialitas Akuntan Publik. Jurnal Akuntansi dan Keuangan Vol.11 No. 1pp.13-20

Ifada \& Ja'far, M. (2005). Pengaruh Sikap Profesionalisme Internal Auditorterhadap Peranan Internal Auditor dalam Pengungkapan Temuan Audit.Jurnal Bisnis, Manajemen dan Ekonomi. Vol.7 No. 3 pp.13-24

Institut Akuntan Publik Indonesia. (2011). Standar Profesionel Akuntan Publik 31 Maret 2011. Jakarta: Salemba Empat.

Jaworski, B.J.\& Young, S.M. (1992). Dysfunctional Behavior and Management Control: An Empirical Study of Marketing Managers. Accounting, Organizattion and Society 17 (1), pp. 17-35

Kusuma, N.F. (2012). Pengaruh Profesionalisme Auditor, Etika Profesi dan Pengalaman Auditor terhadap Pertimbangan Tingkat Materialitas. (Unpublished Thesis). Yogyakarta: Universitas Negeri Yogyakarta.

Muhammad. (2004). Etika Bisnis Islami. Yogyakarta: UPP AMP YKPN.

Noveria. (2006). Pengaruh Profesionalisme Auditor Internal terhadap WorkOutcome Audior Internal. (Unpublished Thesis). Bandung: University of Padjajaran.

Sukmawati, N.L.G, et.al. (2014). Pengaruh etika profesi, kecerdasan intelektual, kecerdasan emosional dan kecerdasan spritual terhadap opini audit (Studi empiris pada Kantor Akuntan Publik Wilayah Bali. e-Journal Universitas Pendidikan Ganesha Jurusan Akuntansi Program S1, Vol:2 No:1..http://e-journal.uajy. ac.id/view/types/thesis.html

Suraida. (2005). Uji Model Etika, Kompetensi, Pengalaman Audit dan Resiko Audit Terhadap Skeptisisme Profesional Auditor. Jurnal Akuntansi, Vol. IX/02/Mei. pp.18-26

Soobaroyen, T. (2006). Management Control System and Dysfunctional Behavior: an Empirical Investigation. Management accounting section meeting conference reviewers

Wahyudi, P.D. (2014). Hubungan etika profesi, keablian, pengalaman dengan ketepatan waktu pemberian opini dalam audit laporan keuangan melalui pertimbangan materialitas dan skeptisme profesional auditor. Jurnal Akuntansi Fakultas Ekonomi Riau Vol.1 No. 2. pp 1-15

Wijayanti, G.L. (2012). Peran Kecerdasan Emosional Dan Kecerdasan Spiritual Dalam Meningkatkan Kinerja Auditor. Jurnal Ilmiah Mahasiswa Akuntansi Vol 1, No.2. Maret 2012, pp 38-42 
Al-Iqtishad: Jurnal Ilmu Ekonomi Syariah (Journal of Islamic Economics) Vol. 8 (1), January 2016

Wiyantoro, L.S. (2008). Hubungan antara sistem pengendalian manajemen dengan perilaku dysfunctional: budaya nasional sebagai variabel moderating. SNA XII Pontianak 